\title{
APPLICATION OF INTELLIGENT TECHNOLOGIES IN THE MANAGEMENT OF SUPPLY CHAINS
}

\author{
Dušan Regodić \\ Poslovni i pravni fakultet, Univerzitet „Union - Nikola Tesla“, Beograd, \\ Srbija
}

\section{Marija Matotek}

Visoka tehnička škola strukovnih studija, Zrenjanin, Srbija

\section{Radomir Regodić}

Zavod za izdavanje udžbenika, Beograd, Srbija

CMESTE

JEL Category: 018, R41

\section{Apstrakt}

Cilj ovog rada je da se prikaže da efektivna implementacija savremenih informacionih sistema $u$ kompanijama i njihova dostupnost putem Interneta (cloud computing) omogućavaju racionalnije $i$ kvalitenje upravljanje lancima snabdevanja. Primenom novih informacionih sistema, računarstva $u$ oblaku, elektronskog poslovanja $i$ sistema za podršku odlučivanju povećavaju se efikasnost $i$ efektivnost. Kompanije kvalitetnije, jednostavnije, brže $i$ uz manje troškove rešavaju složene procese savremenog razvoja, nove integracije tržišta, zahteve klijenata, različitih razvojnih i proizvodnih lokacija, dobavljača i proizvođača, projektovanja i proizvodnje. Cloud computing, kao nova web tehnologija, sve više se koristi u poslovnom svetu. Efekti korišćenja ove tehnologije u poslovanju su brojni. Cloud computing se može implementirati u širokom spektru poslovnih procesa, u cilju efikasnog upravljanja. Brojne veze aktera u e-lancu snabdevanja, e-proizvodnji i e-trgovini zahtevale su nove softvere za skladištenje, obradu, upravljanje, saradnju, analizu, kreiranje i simulaciju. Razvijaju se inteligentni softverski sistemi koji obezbeđuju autonomnost svim akterima pri pregovaranju oko složenih procesa u lancu snabdevanja $i$ simulacije ovih procesa u virtuelnom svetu. Na nivou 6PL, uslovi interakcije učesnika u logističkom lancu snabdevanja se formiraju u integrisanom informacionom okruženju. Softverska platforma 6PL može se koristiti u logističkim sistemima. U radu su prikazani rezultati analize savremenih nivoa logističkih usluga. Primenom savremenih informacionih i komunikacionih tehnologija ostvarena je virtuelizacija interakcije između učesnika u lancu snabdevanja.

Adresa autora zaduženog za korespodenciju:

Dušan Regodić

恝; dusanregodic5@gmal.com
Ključne reči: cloud computing, informacioni sistem, logistički operator, lanac snabdevanja, sistem za podršku odlučivanju. 


\section{Abstract}

The aim of this paper is to demonstrate that the effective implementation of modern information systems in companies, as well as their availability through cloud computing, enable higher quality management of supply chains. The use of new information systems, such as cloud computing, e-business, and decision support systems, increases the company's efficiency and effectiveness. Companies can now address multifaceted processes, new market integrations, and customer requirements in a faster, simpler and more affordable way. Cloud computing, as a new web technology, is becoming increasingly popular in the business world. The effects of using this technology in today's business environment are numerous. Interwoven relationships between participants in the e-supply chain, eproduction and e-commerce required the creation of new software for storage, processing, management, collaboration, analysis, creation, and simulation. Intelligent software systems are being developed to ensure autonomy for all stakeholders in the supply chain, as well as to simulate process development in the virtual world. At the level of the software platform 6PL, the conditions of the interaction of the participants in the logistics supply chain are formed in an integrated information environment. The 6PL software platform can be used in logistics systems. Furthermore, this paper presents the results of the analysis of modern level logistics services. Virtualization of the interaction between the participants in the supply chain was realized using modern information and communication technologies.

Keywords: cloud computing, information system, logistic operator, supply chain, decision support system.

\section{UVOD}

Kompleksnost procesa savremenog razvoja i proizvodnje zahteva nove integracije tržišta, različitih razvojnih i proizvodnih lokacija, dobavljača i proizvođača, projektovanja i proizvodnje, više proizvođača hardverskih i softverskih komponenti. Cloud computing transformiše sve sfere našeg sveta od privrednog života, zabave, kulture, društva, obrazovanja, itd. (Quinn, Strauss, \& Kristandl, 2014). Ova tehnologija utiče i na sve aspekte poslovanja, i pronalazi svoju primenu u istraživanju, dizajnu proizvoda i usluga, proizvodnji, logistici, marketingu i finansijama, slika 1.

1980-te

1990-te

2000-te

2010-te

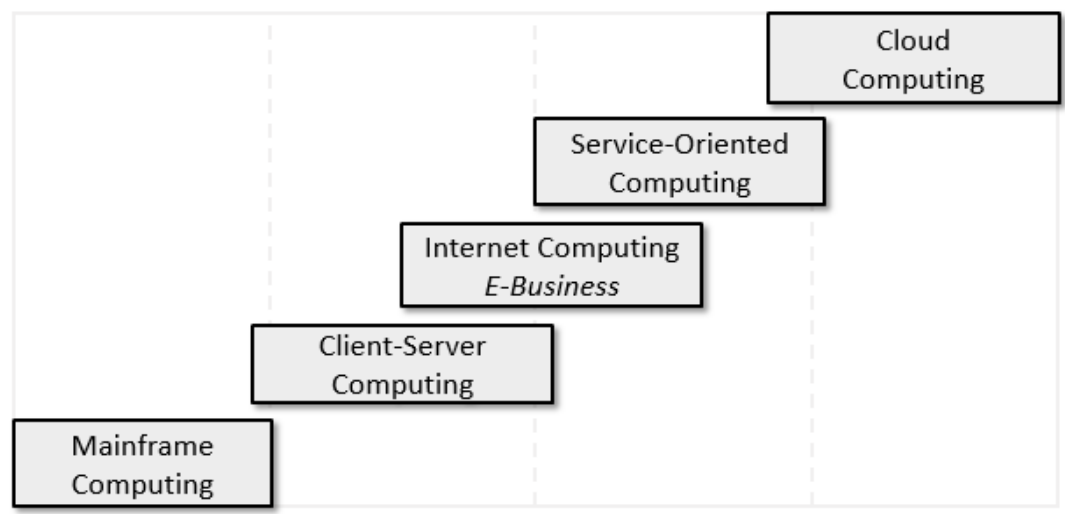

Servisi:

Centralizovani servisi

Deljeni servisi

Samouslužni servisi

Softver: Centralizovan

Decentralizovan

Distribuiran

Slika 1: Razvoj softvera i servisa

U savremenom poslovanju termin "cloud" se poistovećuje sa dostupnošću, lakoćom i brzinom upravljanja podacima (Hui \& Yu, 2010). Reč je o savremenoj tehnologiji koja u značajnoj meri može da unapredi efikasnost poslovnih procesa i redukuje troškove. U razvijenim ekonomijama, sve veći broj preduzeća uviđa prednosti korišćenja ove tehnologije u poslovanju. Tokom dvadesetog veka (70-ih godina) u SAD je pokrenut projekat integrisane proizvodnje pomoću računara (ICAM). Realizacijom tog projekta tokom 1983. godine su definisani osnovni problemi 
tadašnje industrijske automatizacije: sistemi i fuinkcionalne jedinice nisu integrisani, nemogućnost lakog upravljanja informacijama od strane korisnika, zahtevane promene su skupe i dugotrajne, i kvalitet podataka nije pogodan za integraciju.

Tokom kraće primene 90-tih godina dvadesetog veka identifikovane su prednosti integracije kroz bazu podataka: mogućnost komunikacije između različitih funkcionalnih jedinica proizvodnog sistema, tačan prenos podataka unutar i između sopstvenih proizvodnih pogona, brža reakcije na zahtevane promene, povećana fleksibilnost $u$ smislu uvođenja novih proizvoda, povećanje preciznosti i kvaliteta u proizvodnim procesima, povećanje kvaliteta proizvoda, efikasna kontrola $i$ upravljanje tokovima podataka između različitih funkcionalnih jedinica, smanjenje vremena razvoja i proizvodnje i unapređenje proizvodnog toka od narudžbe do isporuke. Osetila se potreba za povezivanjem eksternog toka materijala, informacija, novca i usluga, od dobavljača sirovina, preko proizvodnje, skladištenja, pa sve do krajnjeg kupca. Tako je je prvobitno nastao lanac snabdevanja koji obuhvata organizacije i procese koji kreiraju $\mathrm{i}$ isporučuju proizvode, usluge i informacije krajnjim kupcima. Danas su razvijeni generički modeli arhitekture lanaca snabdevanja u e-okruženju, koji obuhvata eorganizacije, e-nabavku, e-trgovinu i e-saradnju, može poslužiti kao dobra osnova za razvoj specifičnih modela za učesnike na različitim nivoima u mreži lanaca snabdevanja i za ražličite proizvodne i uslužne organizacije (Turban, Aronson, Liang, \& Sharda, 2010).

Razvoj Interneta kao globalne računarske mreže uslovio je nastanak računarstvo u oblaku (cloud computing). Ovaj koncept u računarstvu je omogućio da se računarski resursi isporučuju korisnicima na osnovu njihovog zahteva u vidu usluge, i putem Interneta. Cloud computing se zasniva na tehnologiji virtuelizacije i podrazumeva da se servisi i podaci hostuju u deljenom, dinamički skalabilnom skupu resursa provajdera. Popularnost ove tehnologije raste i u Srbiji. Javljaju se kompanije koje nude usluge cloud computing-a. Efektivna implementacija savremenih informacionih sistema u kompanijama i njihova dostupnost putem Interneta (cloud computing) omogućava primenu savremenih alata za:
- Transformaciju podataka i informacija: grupa podataka iz različitih mašina i procesa postoji na različitim nivoima. Alat za smanjenje podataka, njihovo predstavljanje i usvojena predviđanja za operacione podatke mora da bude razvijen.

- Predviđanje: napredne metode i prediktivni alati moraju da budu razvijeni da bi mogli da otkriju degradacije, greške performansi ili trend "failure not faults", defekte itd.

- Optimizaciju: u okruženju e-proizvodnje podacima se može pristupiti bilo kad i bilo gde. Alati bi trebalo da budu sposobni da upoređuju višestruke, bazne parametre performansi kroz optimalni prikaz kao i da upoređuju proizvodne performanse kroz mrežni monitoring (Network).

- Sinhronizaciju: sinhronizujući elementi obezbeđuju potrebnu integraciju sa sistemima e-poslovanja uključujući CRM, SCM, B2B, sisteme e-trgovine. Sinhronizacije elemenata predviđa integraciju sa e-poslovnim sistemima uključujući CRM, SCM i B2B e-trgovinu.

Teorijski, ova tehnologija predstavlja pogodno rešenja za realizaciju infrastrukture poslovnih sistema, uz smanjenje troškova ulaganja $u$ infrastrukturu i postizanja visokog stepena skalabilnosti i dostupnosti (Armbrust, et al., 2010).

Uloge koje se mogu uočiti u cloud computing-u su:

- Prodavac - preduzeće koje kao posrednik prodaje cloud usluge krajnjim korisnicima.

- Provajder - preduzeće koje je vlasnik cloud servisa, koje nudi korisnicima.

- Korisnik - pojedinac ili preduzeće koje koristi cloud servise.

Danas se putem Interneta i web browser-a može bez problema pristupiti hardverskim i softverskim resursima koji se nalaze na lokacijama koje su izvan fizičkih granica kompanije. U teoriji postoje brojne definicije cloud computing-a, ali nijedna od njih ne može se smatrati opšte prihvaćenom. Kao jedna od najpotpunijih definicija, uzima se ona koju je dao Nacionalni institut za standarde i tehnologiju Sjedinjenih Američkih Država (NIST), prema kojoj je cloud computing "model koji omogućava pogodan pristup po zahtevu" mreži zajedničke grupe podesivih računarskih resursa (npr. mreža, serveri, skladišta, aplikacija i usluga) koje mogu brzo snabdevati korisnike uz 
minimalan napor upravljanja ili interakcije sa provajderom usluge. NITS je takođe definisao i osnovne karakteristike cloud computing-a, a one uključuju (Mell \& Grance, 2011): pružanje usluga na zahtev korisnika, širok mrežni pristup, udruživanje resursa, brzu elastičnost i merljivu upotrebu. Pružanje usluga na zahtev korisnika (on-demand self-servis) podrazumeva da korisnici mogu samostalno da odaberu i pokrenu kompjuterske resurse koji su im neophodni. Široki pristup mreži (broad network access) podrazumeva da su usluge dostupne preko mreže, a njima se može pristupiti putem standardnih uređaja, kao što su mobilni telefoni, tablet računari, laptopovi, itd. Udruživanje resursa (resource pooling) kompjuterski resursi provajdera spajaju se uz pomoć tzv. Muli-Tenant modela kako bi više korisnika istovremeno moglo da koristi cloud usluge, sa različitim fizičkim i virtuelnim resursima, koji se dodeljuju i uklanjaju na zahtev korisnika. Brza elastičnost (rapid elasticity) cloud computing usluge mogu biti brzo i elastično pokrenute, nekada i automatski, kako bi se resursi prilagodili trenutnim potrebama korisnika. Dostupni kapaciteti su često bez ograničenja i može im se pristupati u bilo koje vreme. Merljiva upotreba (measured service). Cloud sistemi automatski kontrolišu i optimiziraju korišćenje resursa. Korišćenje resursa može biti praćeno, kontrolisano i o njemu se mogu kreirati izvještaji, koji omogućavaju transparentnost za provajdera i korisnika usluge.

\section{RAZVOJNI MODELI RAČUNARSTVA U OBLAKU}

Računarstvo u oblaku omogućava tri osnovna tipa razvojnih modela, u zavisnosti od tipa usluge koja se isporučuje korisniku: infrastruktura kao servis, platforma kao servis i softver kao servis, slika 2 (Mell, \& Grance, 2011).

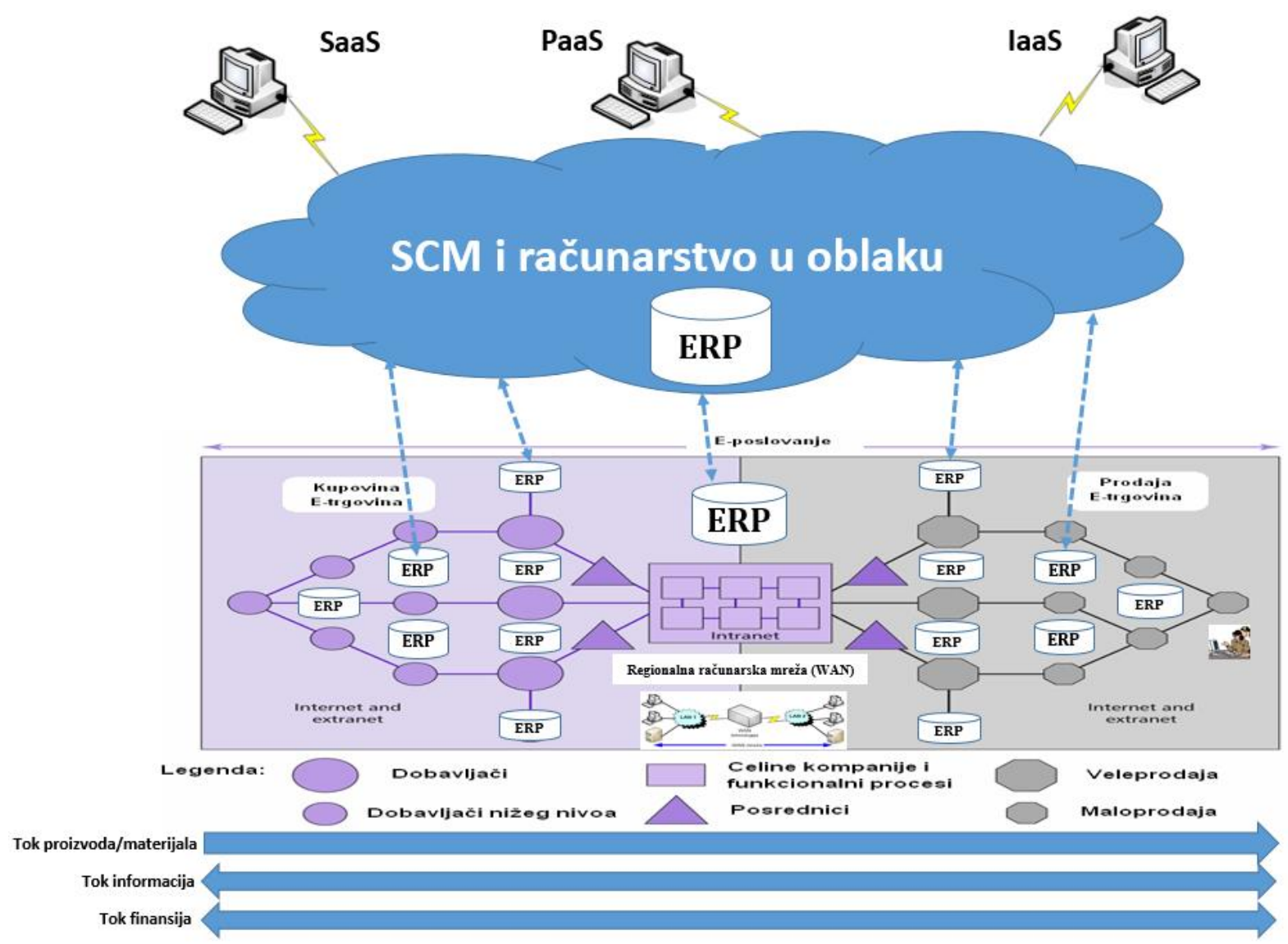

Slika 2: SCM računarstvo u oblaku

Infrastruktura kao servis (laaS). Računarski i mrežni resursi, kao što su procesorska snaga, prostor na disku, memorija, mrežni kapacitet, ruteri, fajervol, i sl. korisniku se isporučuju kao usluga; instalacija i konfiguracija sistema su u nadležnosti korisnika. Korisnik može kod 
provajdera oblaka rezervisati resurse koji su mu potrebni i dinamički menjati te resurse u skladu $\mathrm{s}$ potrebama. Korisnik provajderu plaća za infrastrukturu koju koristi na sličan način kao što plaća račun za električnu energiju ili za mobilni telefon. Iznos računa zavisi od potrošnje i/ili od predefinisanog tarifnog paketa.

Međutim, da bi laaS bio dostupan korisnicima, neophodan je softver koji provajderima oblaka omogućava administraciju infrastrukture, jednostavno dodeljivanje resursa korisnicima, upravljanje infrastrukturom i merenje performansi. Neki od alata za upravljanje oblakom su: OpenStack, OpenNebula, Eucalyptus, AppLogic i drugi. Kao globalni provajderi oblaka ističu se: Amazon AWS i Racksapce. Brojni lokalni provajderi Internet ili telekomunikacionih usluga proširuju svoju ponudu nudeći infrastrukturu kao servis.

Platforma kao servis (PaaS). Platforma omogućava korisniku skup alata i aplikativnih programskih interfejsa (API) koji se mogu koristiti za razvoj aplikacija. Korisnik ne može da upravlja hardverskim resursima na kojima se aplikacija izvršava, već samo ima kontrolu nad aplikacijom koju razvija. Primeri platformi su: Google AppEngine i Microsof Azure.

Softver kao servis (SaaS). Korisniku se omogućava da koristi gotov softver koji je razvio provajder. Softver se pokreće na cloud computing infrastrukturi, a korisnik mu pristupa najčešće kroz veb-brauzer. Brojni su primeri softvera koji se korisnicima nudi kao servis, besplatno ili kao freemium model: elektronska pošta (Gmail, Hotmail, Yahoo, i drugi), čuvanje podataka (Dropbox, Google Drive, Microsoft OneDrive, iCloud i drugi), ali i onih koji nude softver za različite poslovne funkcije, kao što su:

- Aplikacije za kancelarijsko poslovanje (Microsoft Office, Google Apps for Business, Zoho Office).

- ERP rešenja (Netsuite, Epicor).

- Upravljanje odnosima s klijentima i korisnička podrška (SalesForce).

U zavisnosti od vlasništva, postoje četiri modela razvoja cloud computing infrastrukture:

1. Privatni oblak. Preduzeće koristi koncepte računarstva u oblaku za organizaciju sopstvene računarske infrastrukture. Ovaj pristup najčešće nije pogodan za mala $\mathrm{i}$ srednja preduzeća.

2. Javni oblak. Resursi se dinamički dodeljuju korisnicima, pri čemu korisnik ne zna gde se podaci fizički čuvaju, niti ima potpunu kontrolu nad njihovom zaštitom.

3. Hibridni oblak. Kombinacija javnog i privatnog oblaka, u smislu da se deo podataka drži u privatnom a deo u javnom oblaku.

4. Zajednički oblak. Više organizacija deli istu cloud infrastrukturu. Oblakom upravlja jedna od tih organizacija, ili neko treće lice.

\section{POJAM I DEFINICIJA LOGISTIČKOG OPERATERA}

Logistički operater je činioc koji uspešno dizajnira i optimizira logističku mrežu koja je sve više integrisana u globalni privredni sistem te obavlja razne logističke aktivnosti od dobavljača do tačke prijema i uz minimalne uložene resurse maksimalno zadovoljava zahteve tržišta. Aktivnosti logističkog operatera možemo najbolje prikazati kroz lanac snabdevanja. Sistem lanca snabdevanja obuhvata međudelovanje uključenih subjekata, kao što su: kupci, dobavljači sirovina i repromaterijala, proizvođači finalnih proizvoda, distributeri (veletrgovci), maloprodajni trgovci, logistički operatori i prevoznici. Međudelovanje se ogleda u odvijanju tokova roba, informacija i financijskih sredstava između i unutar pojedinih faza lanca snabdevanja.

U uslovima globalizacije prioritet imaju mega logistički operateri, koji se mogu potpuno i vrlo fleksibilno vertikalno integrisati. Proces globalizacije, nameće potrebu razvitka nacionalnih do svetskih tržišta, privrede i društva, uklanjaju se trgovinske barijera, jačaju međunarodna konkurencija, tehnologije. Danas u logistici postoji šest koncepata logističkih operatera:

- 1PL (First Party Logistics) operatera,

- 2PL (Second Party Logistics) operatera,

- 3PL (Third Party Logistics) operatera,

- 4PL (Fourth Party Logistics) operatera,

- 5PL (Fifth Party Logistics) operatera, i

- 6PL (Sixth Party Logistics) operatera.

Koncept 5PL koristi se $u$ transformaciji lanca snabdevanja u mrežu. Poseduje modernu IT platformu sa fokusom na inovacije. 5PL logistički 
operater upravljaju mrežom različitih lanaca snabdevanja (Ivaschenko, 2014).

Oni su često povezani putem e-poslovanja zbog čijeg se uticaja razvila elektronska logistika (elogistika). E-logistika kao aktivnost označava koordinirani, konzistentni i računarski upravljani (podržani, organizirani i kontrolisani) skup složenih intra i interorganizacijskih logističkih fenomena za sve aspekte poslovnih aktivnosti, kojim se može upravljati i voditi putem računarske Internet mreže. Dakle, 5PL operater uglavnom kontroliše protok informacija o naredbama, resursima, planovima i stvarnom stanju transportne mreže. Operator 5PL se uglavnom zasniva na korišćenju modernih informacionih $i$ komunikacionih tehnologija i dovodi do pojave sledećih trendova u upravljanju resursima:

- saradnja kompanija koje učestvuju u lancu snabdeva i široka primena principa outsourcinga;
- pretežno informativna interakcija kupaca i izvršilaca;

- podrška za model SaaS (Softver kao a usluga) na tehničkom i ekonomskom nivou;

- stroga kontrola izvršenja naloga trenutni račun za nadzor statusa;

- distribucija i decentralizacija procesa donošenje odluka.

Ažurirane informacije o procesu isporuke mogu biti stalno obezbeđene. Dakle, 5PL operater uglavnom kontroliše protok informacija o naredbama, resursima, planovima i stvarnom stanju transportne mreže.

Na nivou 6PL, su ostvareni uslovi za interakciju učesnika u lancu snabdevanja snabdevanje $u$ integrisanom informacionom okruženju (Ivaschenko \& Peysakhovich, 2014). Ovi uslovi su izraženi u obliku ugovornih odnosa koji odražavaju stabilnu interakciju između učesnika. $\mathrm{Na}$ slici 3. je ilustracija predloženog rešenja.

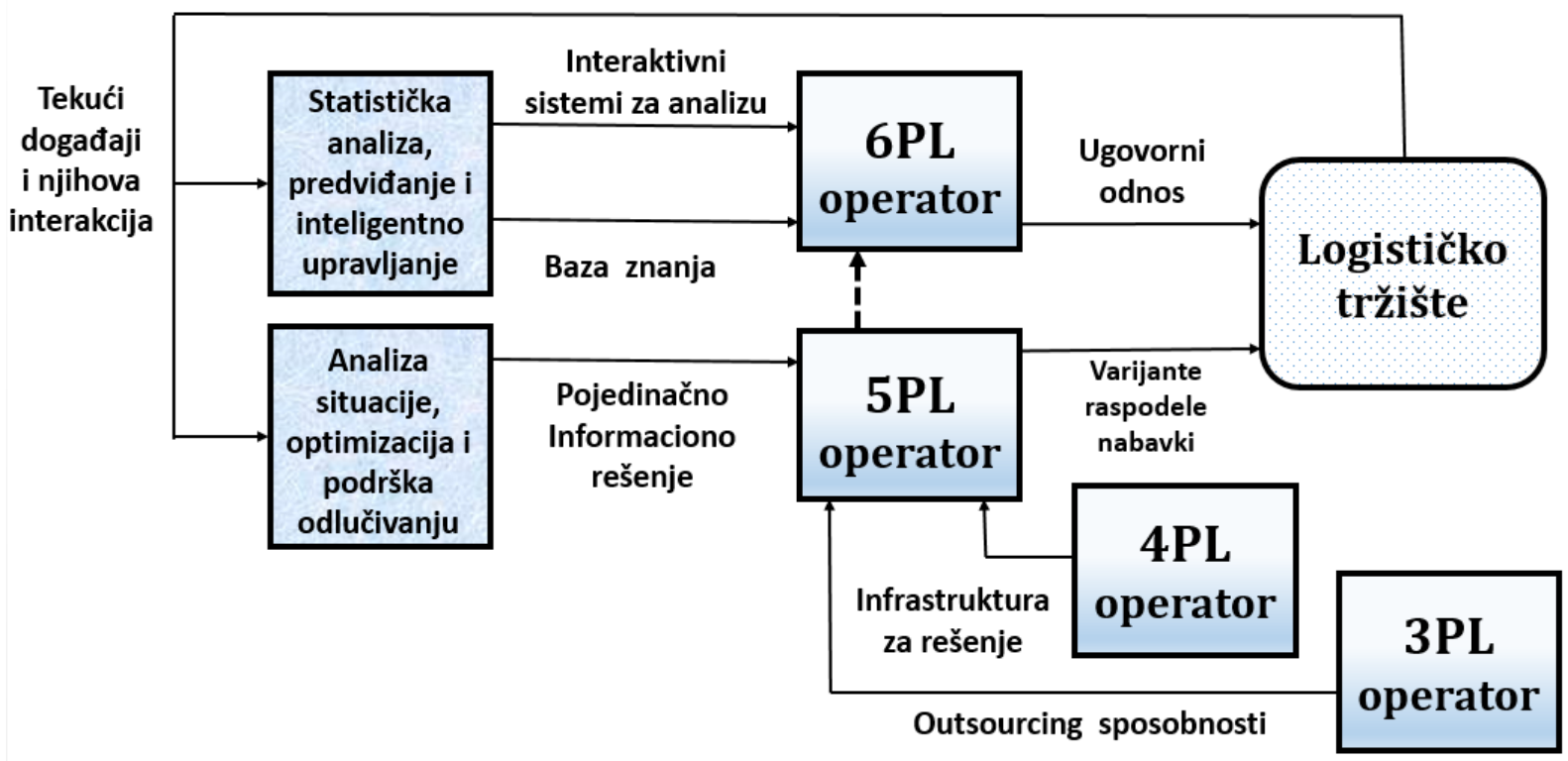

Slika 3: Interakcija operatora u lancima snabdevanja

Operator 5PL poseduje softverske platforme za implementaciju interakcija učesnika u lancu snabdevanja snabdevanje u jedinstvenom informacionom prostoru. Optimizacijom se definišu opcije za izvršavanje naloga i nude in učesnicima. Operator 5PL implementira upravljanje informacijama. Predlozi se formiraju na osnovu analize trenutne situacije operativnim upravljanjem interakcijama između učesnika. Operator 6PL bazira svoj rad na softveru koji se primenjuje na upravljanju sa sistemskim interakcijama. Ovaj softver realizuje sve statističke analize tih interakcija. Predloženi model 6PL-operatora uključuje informaciono okruženje operatora 5PL. Osnova za formiranje održivih interakcija je operativna interakcija na nivou infrastrukture odlučivanja 4PL, a na osnovu informacija iz lanaca snabdevanja. Rezultat predloženog modela su ugovoreni odnosi kao i operativne informacije interakcija. 


\section{SISTEMI ZA PODRŠKU ODLUČIVANJU \\ DSS sistemi kao takvi su složeni i imaju veliki broj različitih implementacija. DSS predstavljan skup \\ Razvojem hardvera postojala je sve veća potreba za razvojem operacionih, analitičkih i specijalizovanih informacionih sistema, slika 4. procedura zasnovan na modelima za obradu i tumačenje informacija koje daju podršku menadžeru u donošenju odluka. Ne postoji opšte prihvaćena definicija.}

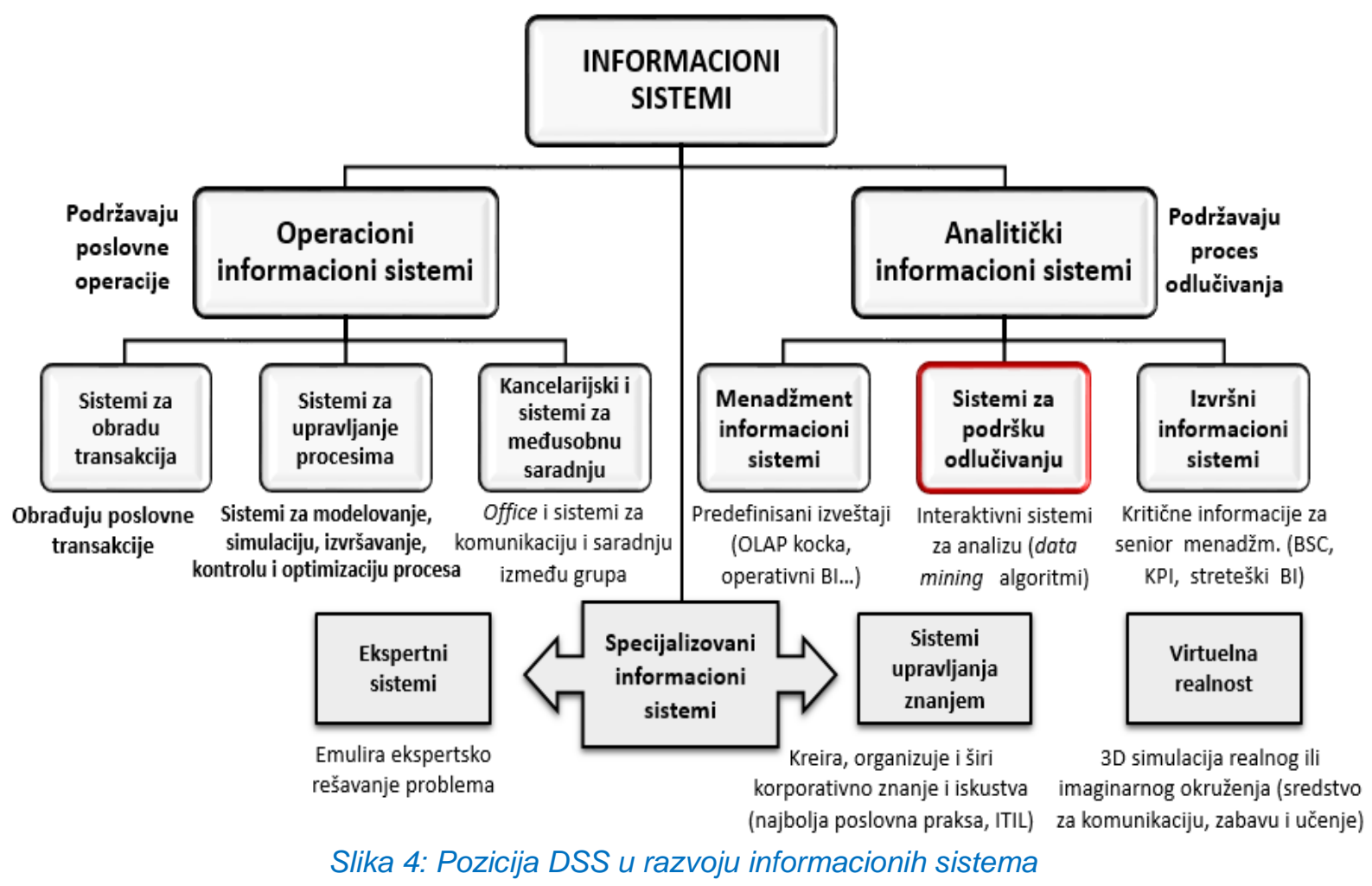

Neka od značenja DSS (Miškovic, 2013):

1. Interaktivni (računarski zasnovan) sistemi ili podsistemi za pomoć donosiocima odluka u:

- korišćenju komunikacionih tehnologija, podataka, dokumenata, znanja i/li modela,

- identifikaciji, rešavanju problema i izvršavanju zadataka u procesu odlučivanja i

- donošenju odluka.

2. Opšti izraz za računarske aplikacije, koje poboljšavaju ličnu ili grupnu sposobnost donošenja odluka.

3. Intraktivni kompjuterski sitemi za ciljem da pomognu menadžerima ili donosiocima odluka da identifikuju, strukturiraju, i/ili reše polustrukturirane i nestrukturirane probleme $\mathrm{i}$ da naprave izbor među alternativama.

4. Naziv akademskog područja, koje istražuje i proučava sisteme za podršku odlučivanju u kontekstu njihove upotrebe.
Odluka jeste rezultat procesa odlučivanja, koja treba delotvorno da reši problem, ali odluka je samo jedna faza kompletnog procesa rešavanja problema. Zato ona mora da bude realna $i$ precizna, nedvosmislena i donešena na vreme. Podrška ne mora biti samo računarska. Prednosti računarske podrške su (Miškovic, 2013):

- Brzina - veliki broj računanja, brzo i po niskoj ceni;

- Prevazilaženje ograničenja u obradi i memorisanju podataka, koja mogu smanjiti sposobnost rešavanja problema (npr. loše pamćenje);

- Tehnička podrška u memorisanju, pretraživanju i prenosu podataka, brže $\mathrm{i}$ jeftinije;

- Kvalitet podrške, kroz bolje odluke, obradu više alternativa, analizu rizika i ekpertsku podršku;

- Smanjenje cene koštanja podrške; i

- Agilnost podrške - brzo donošenje dobrih odluka. 


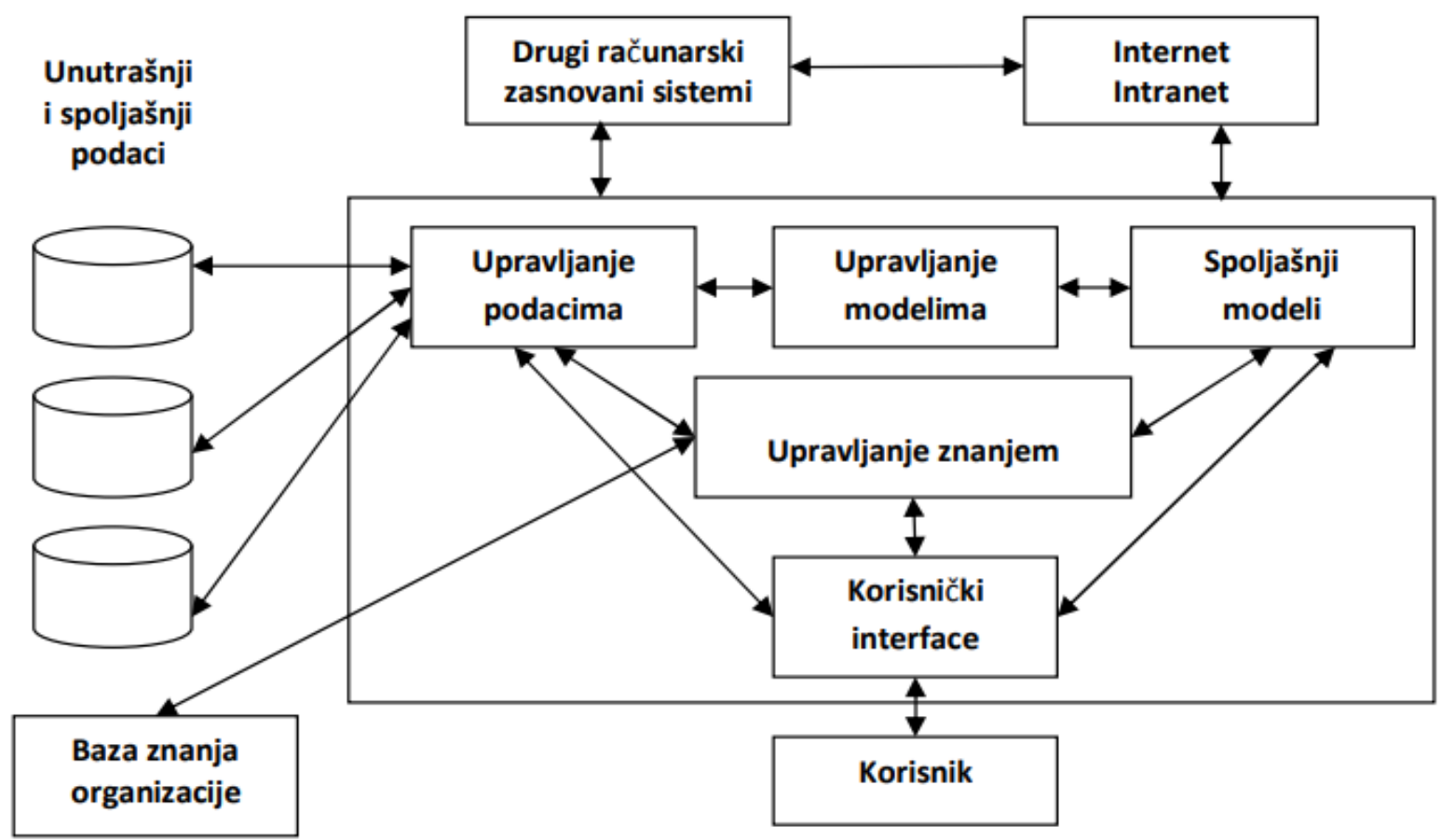

Slika 5: Komponente današnjih DSS

Pojam neizvesnosti se odnosi na nedostatak informacija o objektu i trenutku kada treba doneti odluku. Svaki problem karakteriše nedostatak informacija ili njihova nepouzdanost. Komponente današnjih DSS su podsistemi za, slika 5.: upravljanje podacima, upravljanje modelima, korisnički interfejs i upravljanje znanjem (Miškovic, 2013).

Podsistem za upravljanje podacima obuhvata: bazu podataka koja sadrži relevantne podatke o problemu, Sistem za upravljanje podacima (DBMS - Database Management System), rečnik podataka i upite.

Podsistem za upravljanje modelima se sastoji iz: baze modela, Sistema za upravljanje bazom modela (MBMS - Model Base Management System), rečnik modela, direktorijuma modela i izvođenja modela, integracije i komandnog procesora.

Podsistem - korisnički interface pokriva sve aspekte komunikacije između korisnika i DSS-a. On se ne odnosi samo na hardver i softver veš $i$ na faktore koji se tiču lakoše korišćenja i pristupačnosti sistema i faktore vezane za interakciju čovek-mašina. Jedan od glavnih razloga zašto menadžeri ne koriste kompjutere i kvantitivne analize, onoliko koliko bi one mogle da se koriste, je težak korisnički interfejs. Aktuelnom DSS-u pristupa se preko web browsera, efektivnog grafiškog korisničkog interfejsa (GUI), uključujući i glasovne inpute i outpute, portabl uređaje i direktno očitavanje sa uređaja. Web browser je fleksibilan, naklonjen korisnicima $\mathrm{i}$ gateway skoro svim izvorima neophodnih podataka i informacija. Korisnički interfejs savremenog DSS-a obezbeđuje interakciju sa bazom podataka i bazom modela, dozvoljava da se više funkcija izvršava istovremeno, predstavlja podatke u različitim formatima, obezbeđuje učenje kroz primere itd., što u velikoj meri olakšava rad korisnicima (zaposlenima na svim nivoima u organizaciji) i doprinosi velikoj upotrebi DSS-a.

Podsistem za upravljanje znanjem (Miškovic, 2013) može da podržava bilo koji podsistem ili da deluje kao samostalna komponenta. Glavna karakteristika koja izdvaja ovaj podsistem od ostalih je postojanje baze znanja, što omogućava korisniku ekspertizu o postavljenom problemu.

Komponente podsistema mogu se obezbediti putem ekspertnih sistema, neuronskih mreža, inteligentnih agenata, fazi logike itd. DSS koji poseduje ovaj podsistem naziva se inteligentni DSS ili DSS baziran na znanju (knowledge-based DSS). Osnovne faze u procesu donošenja odluka (Simon, 1960) su: prikupljanje informacija (intelligence); kreiranje rešenja (design), model; izbor rešenja (choice); primena rešenja (implementation), slika 6. 
U okviru nauke o menadžmentu razvijen je veliki broj metoda za rešavanje važnih praktičnih problema: linearno programiranje, mrežna optimizacija (network optimization), teorija repova (queuing theory), teorija igara (games theory).

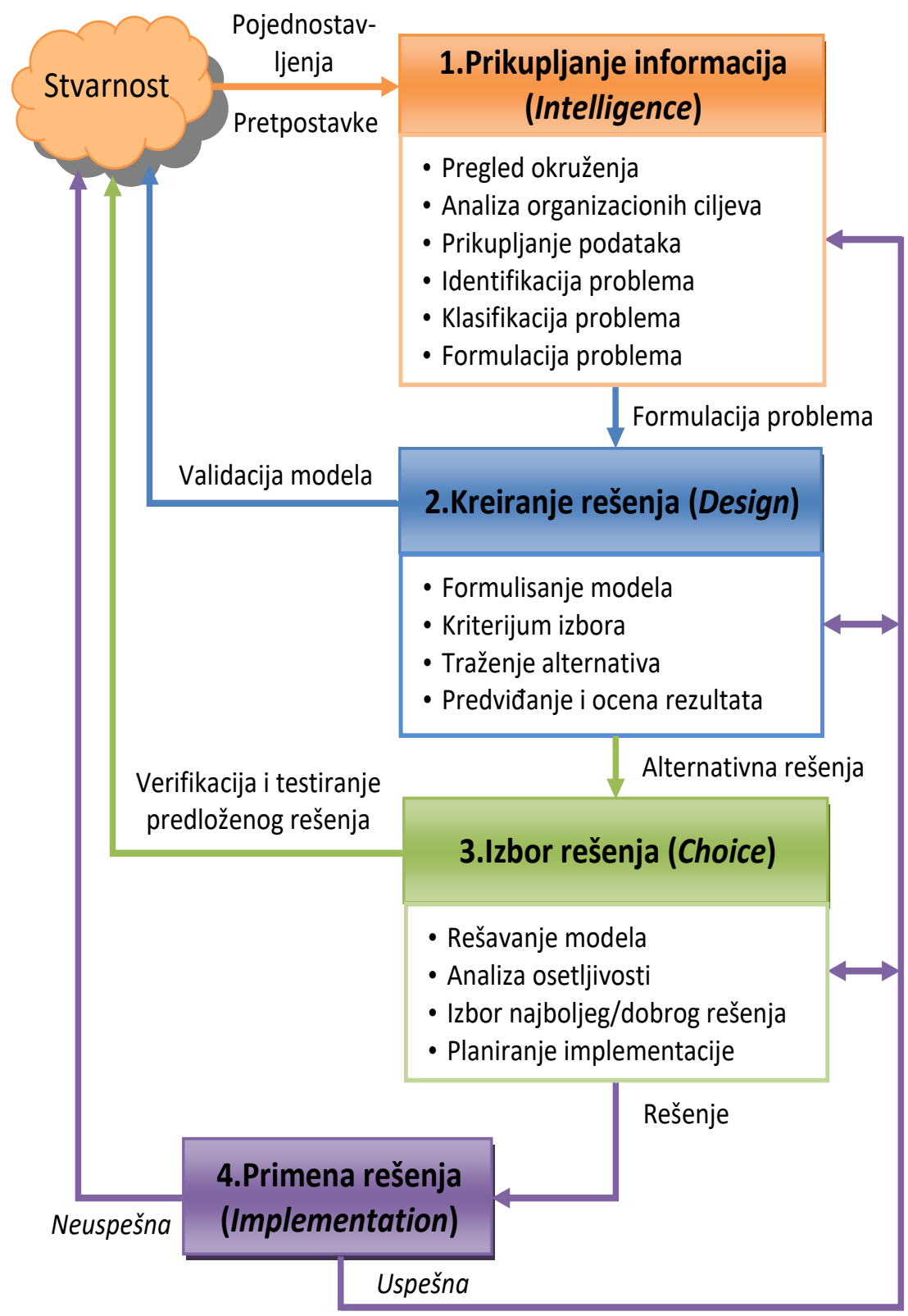

Slika 6: Osnovne faze u procesu donošenja odluka

Mnogi problemi optimizacije se mogu pogodno formulisati za rešavanje metodom linearnog programiranja i njegovim generalizacijama. Prikazaće se dva pristupa rešavanju poznatog problema upravljanja zalihama (inventory management): jednostavno analitičko rešenje i složenija računarski zasnovana rešenja.

\subsection{Primena DSS pri upravljanju sa zalihama}

Zalihe su sve količine materijala, energije i informacija koje su određeno vreme isključene iz procesa proizvodnje ili upotrebe (potrošnje) sa ciljem da se u datom trenutku ukazane potrebe mogu iskoristiti (Regodić, 2014). Pri upravljanju zalihama postoje brojni i različiti problemi odlučivanja: Koje i kolike zalihe su potrebne? Kako in formirati? Kako in pratiti i kontrolisati? Kako ih popunjavati u vremenu? Koji su faktori koji in limitiraju i na koji način? Upravljanje zalihama ima uticaj na sve poslovne funkcije, posebno proizvodnju, marketing i finansije. 


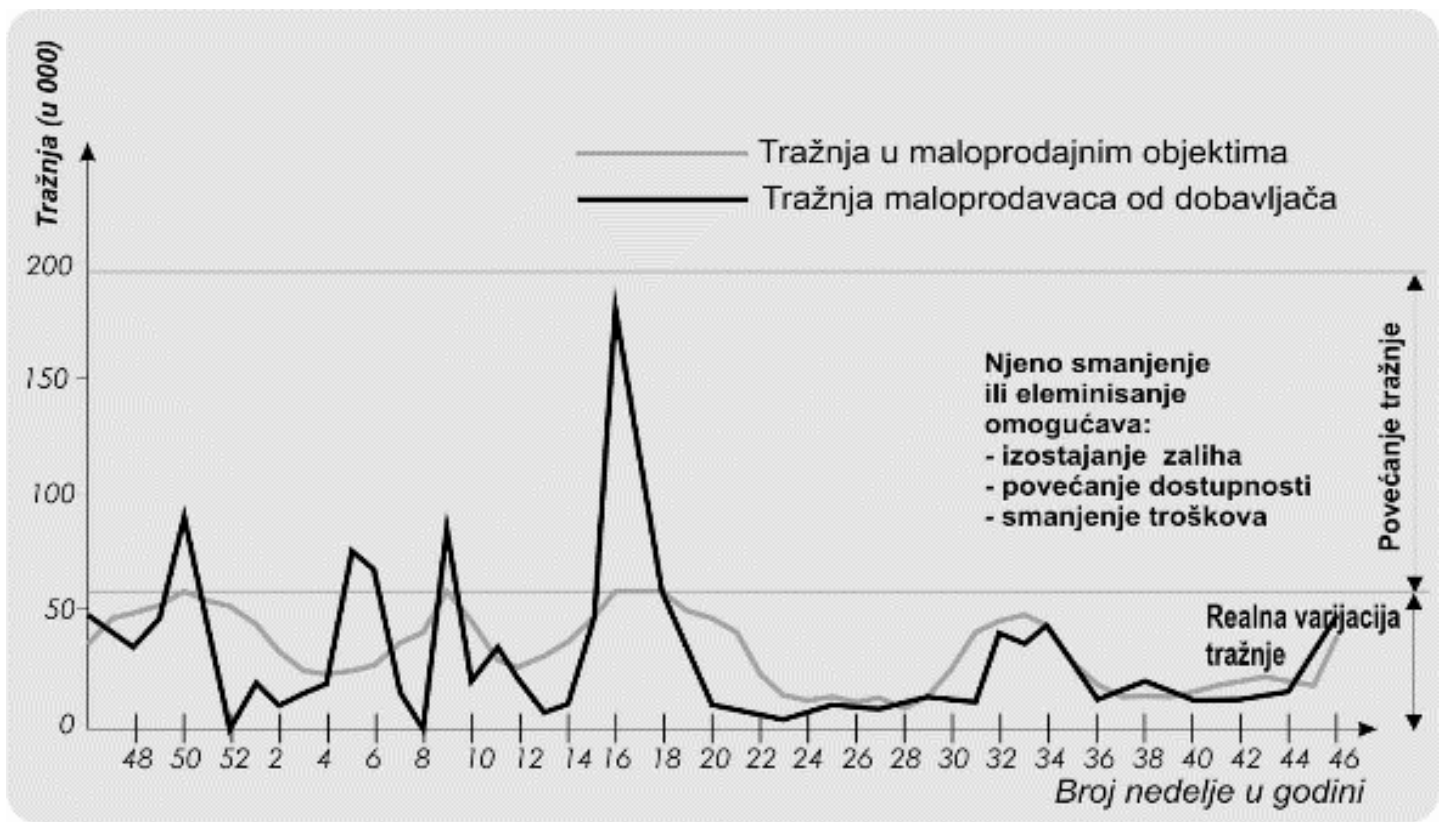

Slika 7: Povećanje varijacija tražnje i pojava efekta jakog biča (Regodić, 2014).

Zalihe osiguravaju uslugu potrošačima, što je od životnog interesa za marketing. Nepravilno upravljanje zalihama dovode do efekta jakog biča (bulhwhip effect), slika 7.

Kvalitetno upravljanje zalihama je ključ za profitabilnost firme. Optimalne zalihe predstavljaju onaj obim robe na skladištu koji uslovljava najniže troškove nabavke, skladištenja i prodaje po jedinici. To je najpoželjniji nivo zaliha jer je za trgovinu najekonomičniji. Optimalni nivo može da se poklapa i sa minimalnim i sa maksimalnim zalihama, ali češći je slučaj da se nalazi negde između njih.

Ukupne troškove, počev od nabavne cene robe, pa do poslednjeg troška u vezi sa skladištenjem, moguće je podeliti u dve grupe, slika 8. (Regodić, 2014):

- troškovi nabavke (Tn),

- troškovi držanja zaliha (Tdz).

Troškove zaliha teško je proceniti, ali je ipak moguće i dovoljno za donošenje odluka. Najvažnije komponente troškova nabavke su troškovi naručivanja i dopreme. Troškovi naručivanja vezani su za naručivanje serije ili partije proizvoda. Troškovi naručivanja su uglavnom fiksnog karaktera, s obzirom da vrlo malo zavise od naručene količine. Ovi troškovi uključuju troškove pisanja narudžbe i otpreme, troškove prevoza, troškove preuzimanja partije.
Takođe, postoje troškovi vezani za izvršenje narudžbe koji su nezavisni od broja izrađenih predmeta. Troškovi izmene uključuju administrativne troškove potrebne za pripremu proizvodne opreme za izradu serije, troškovi kvalitativnog i kvantitativnog prijema robe, lični dohoci nabavne službe i sl. Ovi troškovi se često smatraju fiksnim, a mogu se smanjiti promenom načina na koji je proizvodnja zasnovana. Troškovi predmeta predstavljaju troškove proizvodnje ili kupovine pojedinih predmeta za zalihe. Trošak predmeta je izražen kao trošak po jedinici proizvoda pomnožen nabavljenom ili proizvedenom količinom. Ponekad se na trošak daje popust, ako se odjednom kupi dovoljna količina jedinica. Troškovi dopreme su uglavnom proporcionalnog karaktera. Ovde spadaju troškovi prevoza, utovara, pretovara, istovara, osiguranja, kalo, lom, rastur i ostali gubici na kvalitetu i kvantitetu robe, koji mogu nastati za vreme njenog transporta. Zajedno uzeti, troškovi naručivanja i dopreme najčešće imaju relativno fiksni karakter, ali se radi njihovog lakšeg grafičkog prikazivanja obično pretpostavlja da su proporcionalni sa brojem narudžbina.

Troškovi držanja zaliha sastoje se od kamata na angažovana obrtna sredstva, troškova amortizacije, zastarevanja, kirija, svetla, ogreva, poreza i troškova manipulacije sa robom na zalihi. 


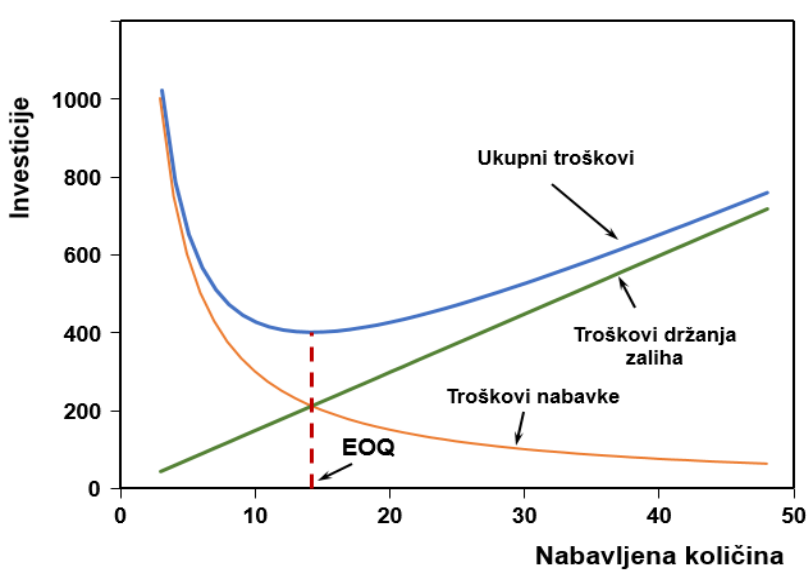

Slika 8: Odnos troškova držanja zaliha i troškova nabavke (Regodić, 2014).

Troškovi čuvanja ili održavanja - vezani su sa držanjem predmeta na zalihama tokom nekog vremenskog perioda. Troškovi održavanja zaliha sastoje se od tri komponente: troškovi kapitala, troškovi skladištenja i troškovi zastarevanja, kvarenja i gubitaka. Značajne komponente troškova držanja zaliha su tzv. oportunitetni troškovi i troškovi zastarevanja. Zbir ovih troškova čini konačnu cenu koštanja robe, a optimalnim nivoom zaliha smatra se onaj nivo pri kojem je zbir ovih troškova najniži. Oportunitetni troškovi se donose na:

- izgubljeni prihod od mogućeg angažovanja sredstava koja su zarobljena u zalihama a da nisu, i

- izgubljeni prihod od prodaje proizvoda kojih nema a kada bi in bilo na zalihi.

\subsection{Utvrđivanje potreba za zalihama i ekonomična količina narudžbe}

Različiti normativi i nivoi zaliha su uslovili i različite postupke za utvrđivanje nivo zaliha. Stohastički postupak se primenjuje za utvrđivanje potreba za zalihama repromaterijala i poluproizvoda (Regodić \& Stojanović, 2017). Deterministički postupak određivanja potrebnih količina zaliha zasniva se na planovima proizvodnje. Detaljan plan proizvodnje i precizne sastavnice svakog proizvoda su uslov dobrih planova nabavki i zaliha. Sastavnice mogu biti količinske (lista elemenata), strukturne (podaci o strukturi proizvoda) i modularne (za podsklopove). Ovaj postupak zahteva i definisanje normativa zaliha: minimalnih, standardnih, signalnih, optimalnih $i$ maksimalnih.

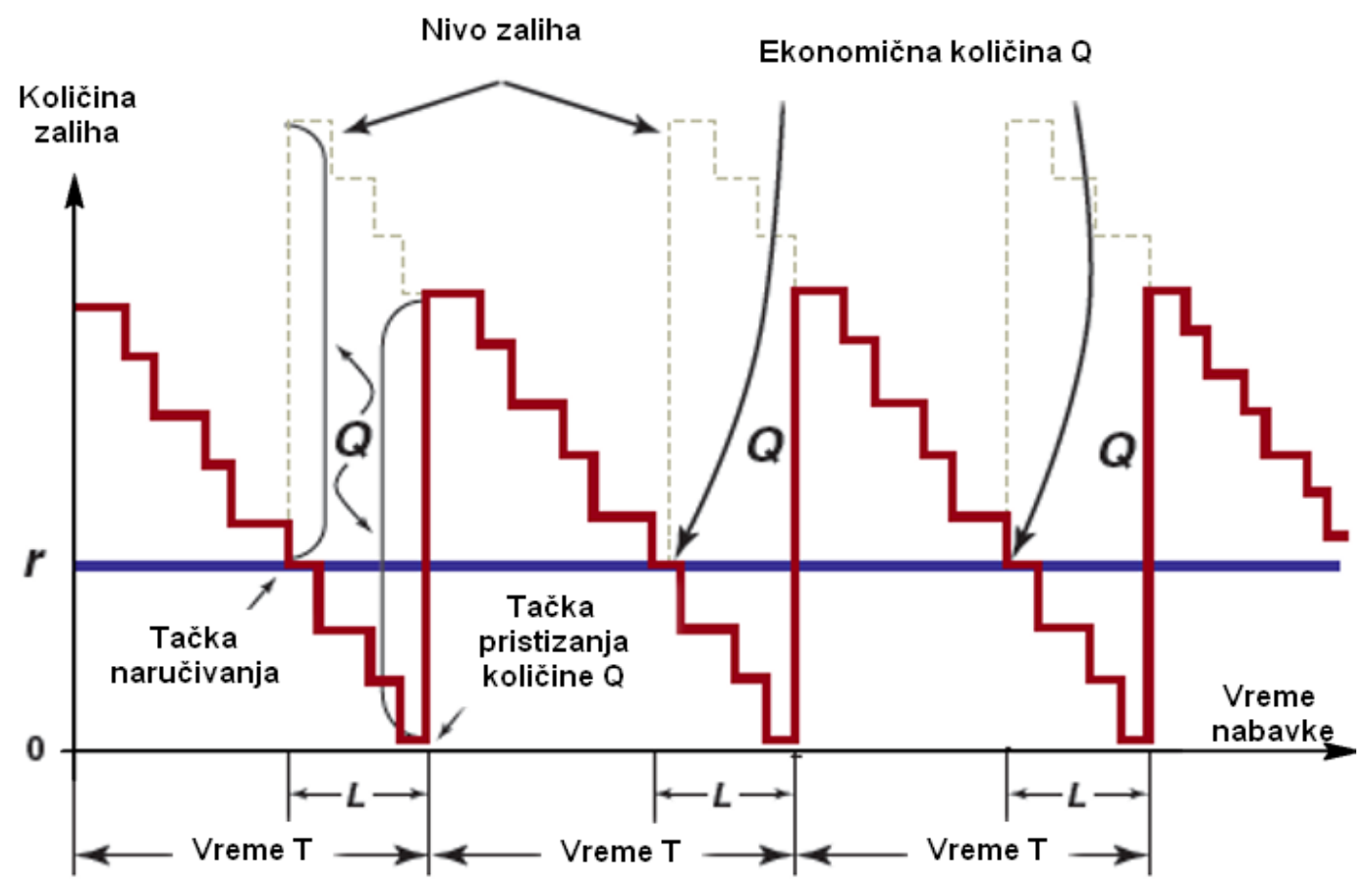

Slika 9: Kontinualna popuna količinama $Q=E O Q$

Detereministički modeli upravljanja zalihama su se razvijali u dva pravca (Regodić \& Stojanović, 2015): klasični i dinamički. Klasični modeli nabavke se zasnivaju na vrednosti ekonomske količine nabavke (EKN) koju je moguće dobiti kroz dva kontradiktorna zahteva. Prvi je: veća količina nabavki, niže cene po jedinici nabavljene robe $\mathrm{i}$ niži troškovi utovara/istovara i transporta. Drugi je 
što manje nabavke, manje novčanih sredstava, niži troškovi skladištenja i kamata na angažovana sredstva. Klasični model se razvijao u dva pravca. Prvi podrazumeva naručivanje (obnavljanje) zaliha u poznatim vremenskim intervalima. Drugi podrazumeva naručivanje zaliha posle svake promene stanja. Razlikujemo periodični ( $P$ sistem) i kontinualni sistem (Q-sistem).

Godine 1915. godine F.W. Harris razvio je formulu ekonomične količine narudžbe (EKN, economic order quanity, EOQ) koja je stekla široku primenu u industriji, slika 9. (Regodić, 2014).

Model za proračun EKN ima mnogo ograničenja (Regodić, 2014):

- za potražnju se pretpostavlja da je konstanta, dok u mnogim realnim situacijama ona značajno varira,

- $\quad$ za jedinične troškove se pretpostavlja da su konstantni, mada u praksi često postoje popusti na količinu kod velikih kupovina,

- $\quad$ za materijal u seriji pretpostavlja se da dolazi odjednom, mada će se u nekim slučajevima kontinuirano smeštati u zalihe zavisno od toga kako se proizvodi,

- $\quad$ pretpostavlja se samo jedan proizvod, mada se od dobavljača nabavlja nekoliko predmeta koji se svi otpremaju u isto vreme,

- $\quad$ troškovi pripreme uzimaju se kao fiksni, dok se često oni mogu smanjiti.

EKN se može izračunati na bazi minimizacije troškova skladištenja i narudžbe. Optimalan broj nabavki se dobija kao odnos planirane potrebe i ekonomične količine nabavke (Regodić, 2014).

gde su:

$$
E K N=\sqrt{\frac{200 \cdot P \cdot T n}{N c \cdot S z}}=\sqrt{\frac{2 \cdot P \cdot T n}{N c \cdot s z}}
$$

- P - procenjena (fiksna) potreba za materijalom/delovima za određeni period/godišnje;

- Tn - procenjeni (fiksni) troškovi nabavke po jednoj nabavci;

- Nc - nabavna cena;

- Sz - stopa troškova držanja zaliha, izražena u \% (0 do 100);

- $\quad$ sz - stopa troškova držanja zaliha, izražena u procentima (0 do 1)

Optimalno vreme između narudžbi (trajanje ciklusa narudžbe):

$$
T_{V Q E O Q}=\frac{E K N}{P}
$$

Trenutni troškovi skladištenja proizvoda $\mathrm{x}$ :

$T_{Z}=\bar{Z} \cdot \mathrm{Nc} \cdot s z+\frac{P}{Z} \cdot T n$

gde su:

- Tz - ukupni troškovi;

- $\quad \bar{Z}$-prosečan nivo zaliha na skladištu:

$$
\bar{Z}=\frac{Z_{\max }+Z_{\min }}{2}=\frac{E K N}{2}+Z_{\text {sig }}=\frac{E K N}{2}+Z \cdot \sigma_{L}
$$

- P - procenjena (fiksna) potreba za materijalom/delovima za određeni period/godišnje;

- $\quad$ Tn - procenjeni (fiksni) troškovi nabavke po jednoj nabavci;

- Nc - nabavna cena;

- Zmax - m,maksimalni nivo zaliha u skladištu $(\mathrm{EKN}+\mathrm{Zsig})$;

- Zmin - minimalni nivo zaliha u skladištu predstavlja očekivanu prodaja/potrebu (P) u jedinici vremena (danu, mesecu) i vremena (V) $Z \min =P \cdot V$;

- $\quad Z=Q-$ količina koja se isporuči tokom jedne porudžbine (EKN);

- Sz - stopa troškova držanja zaliha, izražena u \% (0 do 100);

- $\quad$ sz - stopa troškova držanja zaliha, izražena u procentima (0 do 1);

- $\sigma \mathrm{L}$ - standardno odstupanje potreba (potražnje);

- $\quad$ z - standardizovana slučajna promenljiva.

Teži se iznalaženju modela po kojem nisu fiksne količine nabavke, vreme ponovne narudžbe, niti potrebe. Po metodu promenljivih količina nabavke EKN je u tački gde su troškovi skladištenja i troškovi nabavke minimalni - tački njihovog preseka.

$$
E K N=\sqrt{\frac{2 \cdot P \cdot(T n \cdot Q t n)}{N c q \cdot q \cdot(1 \cdot u s r / i s r)}}
$$

Ukoliko se u izračunavanje EKN uvrste cene koje su pod uticajem nabavljene količine, onda EKN izgleda ovako:

$$
E K N=\sqrt{\frac{2 \cdot P \cdot(T n \cdot Q t n)}{C \cdot q}}
$$

gde su:

- $\quad$ P - nije prosečna potreba, već klizna potreba (potreba koja se menja po periodu); 
- Tn - troškovi nabavke;

- Ncq - nabavna cena po jedinici koja nije jednaka za svaku jedinicu;

- $\quad$ q-broj jednica po nabavci;

- usr - ulazna skladišna rata;

- $\quad$ isr - izlazna skladišna rata;

- C - cene zavisne od količina;

- Qtn - operativni troškovi nabavke (fiksni).

Momenat ponovne nabavke (MPN) se dobija kada se pomnoži vreme izvršenja narudžbe sa dnevnom potrebom. Ovakav način računanja MNP je optimalan kada je konstantna upotreba zaliha. Ukoliko upotreba zaliha nije konstantna, tj. njihova upotreba je neizvesna, onda MPN izgleda ovako:

$M P N=P \cdot T+F n z \sqrt{P \cdot q \cdot T}$

gde su:

- P - planirana potreba;

- $\quad$ T - vreme izvršenja nabavke;

- Fnz - faktor prihvatljivog nedostatka zaliha;

- $\quad$ q-prosečan broj jedinica po jednoj nabavci.

Optimalno vreme skladištenja se dobija na osnovu sledeće formule (Regodić, 2014):
$O V N=\sqrt{\frac{2 \cdot T n}{N c / q \cdot P \cdot q}}$

gde su:

- $\quad$ P - procenjena potreba za svaki period;

- Tn - procenjeni (fiksni) troškovi nabavke po jednoj nabavci;

- Nc/q - nabavna cena zaliha po jedinici (jednaka za svako pakovanje);

- Tdz - prosečan broj jedinica po jednoj nabavci.

Moderni DSS računaju EOQ na osnovu raspoloživih informacija. Uzimaju u obzir dodatne promenljive, kao što je raspoloživi prostor skladišta ili ograničenja dobavljača, povezana s mogućnošću kreditiranja. Na osnovu tih dodatnih informacija, savremeni softver pomaže menadžerima $u$ donošenju boljih odluka $u$ upravljanju zalihama (Miškovic, 2013):

1. Analitičko rešenje (EOQ) i rešenje korišćenjem MS Excel Solvera;

2. Microsoft Office osnovni EOQ model; i

3. Inventory Management DSS.

Tabela 1. Sistem jednačina, pregled upotrebljenih oznaka i ulazni podaci u Excel Solver modelu

\begin{tabular}{|c|c|c|c|c|c|c|}
\hline & Data & & & Results & Range Name & Cell \\
\hline$d=P$ & 6000 & (demand/year) & $\begin{array}{r}\text { Reorder } \\
\text { Point }\end{array}$ & 216 & $\begin{array}{l}\text { Annual Holding } \\
\text { Cost }=h^{*}(Q / 2)\end{array}$ & G7 \\
\hline $\mathrm{K}=\mathrm{Tn}$ & $\$ 115$ & (setup cost) & & & $\begin{array}{l}\text { Annual Setup } \\
\text { Cost }=K^{*}(d / Q)\end{array}$ & G6 \\
\hline $\mathrm{h}=\mathrm{Nc}$ & $\$ 4.20$ & $\begin{array}{l}\text { (unit holding } \\
\text { cost) }\end{array}$ & $\begin{array}{r}\text { Annual } \\
\text { Setup } \\
\text { Cost }\end{array}$ & $\$ 1,203.74$ & d & C4 \\
\hline $\mathrm{L}=$ & 9 & $\begin{array}{l}\text { (lead time in } \\
\text { days) }\end{array}$ & $\begin{array}{r}\text { Annual } \\
\text { Holding } \\
\text { Cost }\end{array}$ & $\$ 1,203.74$ & $\mathrm{~h}$ & $\mathrm{C} 6$ \\
\hline WD $=$ & 250 & $\begin{array}{l}\text { (working } \\
\text { days/year) }\end{array}$ & $\begin{array}{r}\text { Total } \\
\text { Variable } \\
\text { Cost }\end{array}$ & $\$ 2,407.49$ & $\mathrm{~K}$ & $\mathrm{C} 5$ \\
\hline & & & & & L & $\mathrm{C} 7$ \\
\hline & Decision & & & & Q & C11 \\
\hline $\begin{array}{l}\mathrm{EOQ}=\mathrm{Q} \\
=\sqrt{\frac{2 \cdot P \cdot T n}{N C \cdot S z}}\end{array}$ & 573.2115 & & & & $\begin{array}{l}\text { ReorderPoint } \\
=\mathrm{d}^{*}(\text { L/WD })\end{array}$ & G4 \\
\hline & & & & & $\begin{array}{l}\text { TotalVariableCost } \\
=K^{*}(d / Q)+h^{*}(Q / 2)\end{array}$ & G8 \\
\hline & & & & & WD & C8 \\
\hline
\end{tabular}

Primer 1: Analitičko rešenje (EOQ=EKN) rešenje korišćenjem MS Excel Solvera.

Izračunati ekonomičnu količinu naručivanja ako je poznato:

- $\quad$ Predviđena mesečna potražnja: $P=11.107$ jedinica;

- $\quad$ Procenjeni (fiksni) troškovi nabavke po jednoj nabavci: $T n=\$ 10$ po porudžbini;
Nabavna cena: $\mathrm{Nc}=\$ 0,11$ po jedinici;

- Stopa troškova držanja zaliha, izražena u \% (0 do 100): $\mathrm{Sz}=20 \%$ godišnje;

- Standardna devijacija greške predviđanja: $\mathrm{Sd}_{\mathrm{d}}=3.099$ jedinica;

- Vreme izvršenja dopunjavanja: LT $=1,5$ mesec; i

- Verovatnoća da će stavka biti na lageru tokom vremena izvršenja: $P=75 \%$. 
Ekonomična količina za ponovno poručivanje je:

$E O Q=\sqrt{\frac{2 \cdot P \cdot T n}{N c \cdot S z}}=\sqrt{\frac{2(11,107)(10)}{(0,11)\left(\frac{0,20}{12}\right)}}=11,00$ jedinica
Programsko rešenje dato je u tabeli 1 i na slici 10.

MS Excel Solver model pronalazi optimalni $Q$ tako da minimizuje Total Variable Cost (Hillier, 1998)

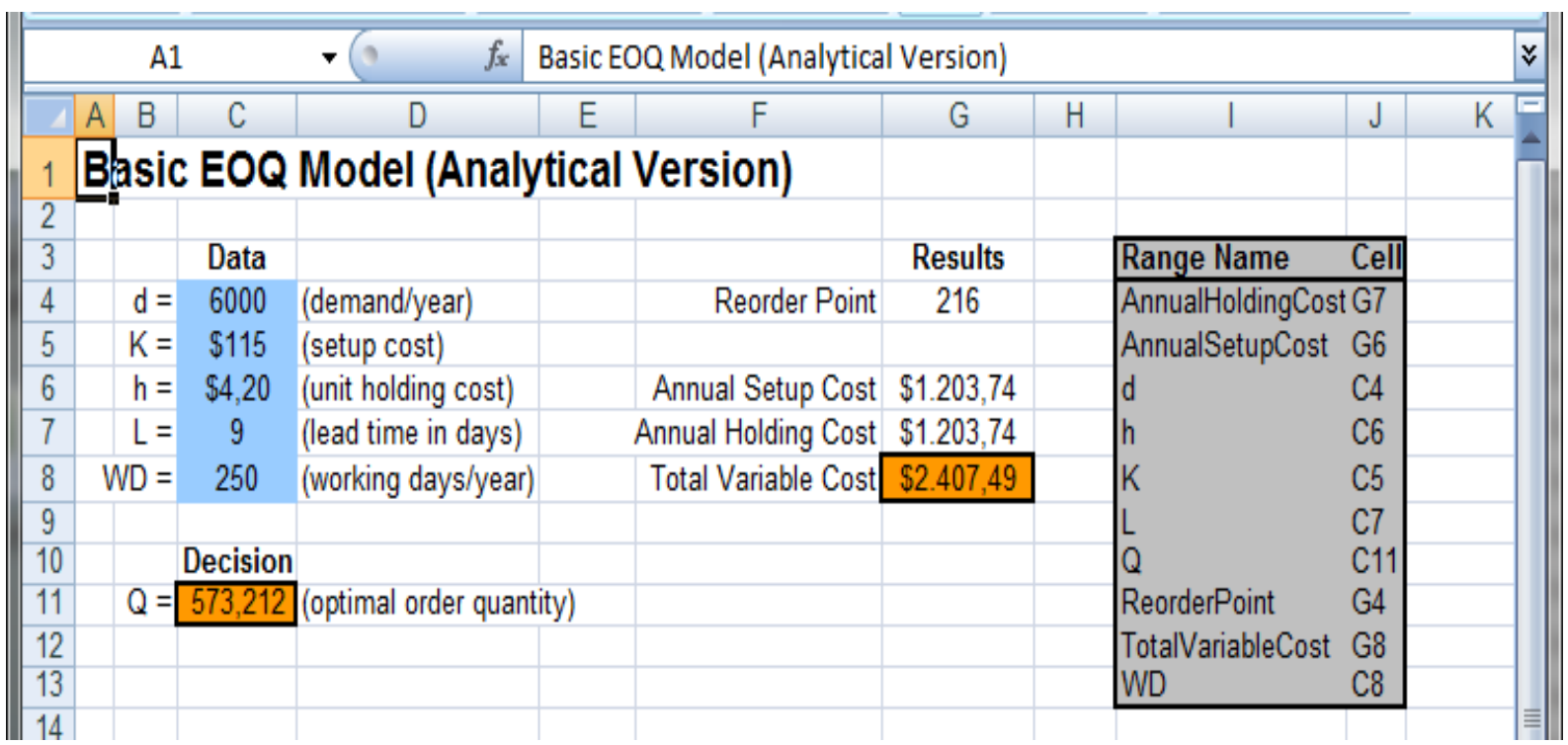

Slika 10. MS Excel Solver model

Primer 2: Microsoft Office osnovni EOQ model, Prikaz je dat na: http://office.microsoft.com/enslike 11 i 12

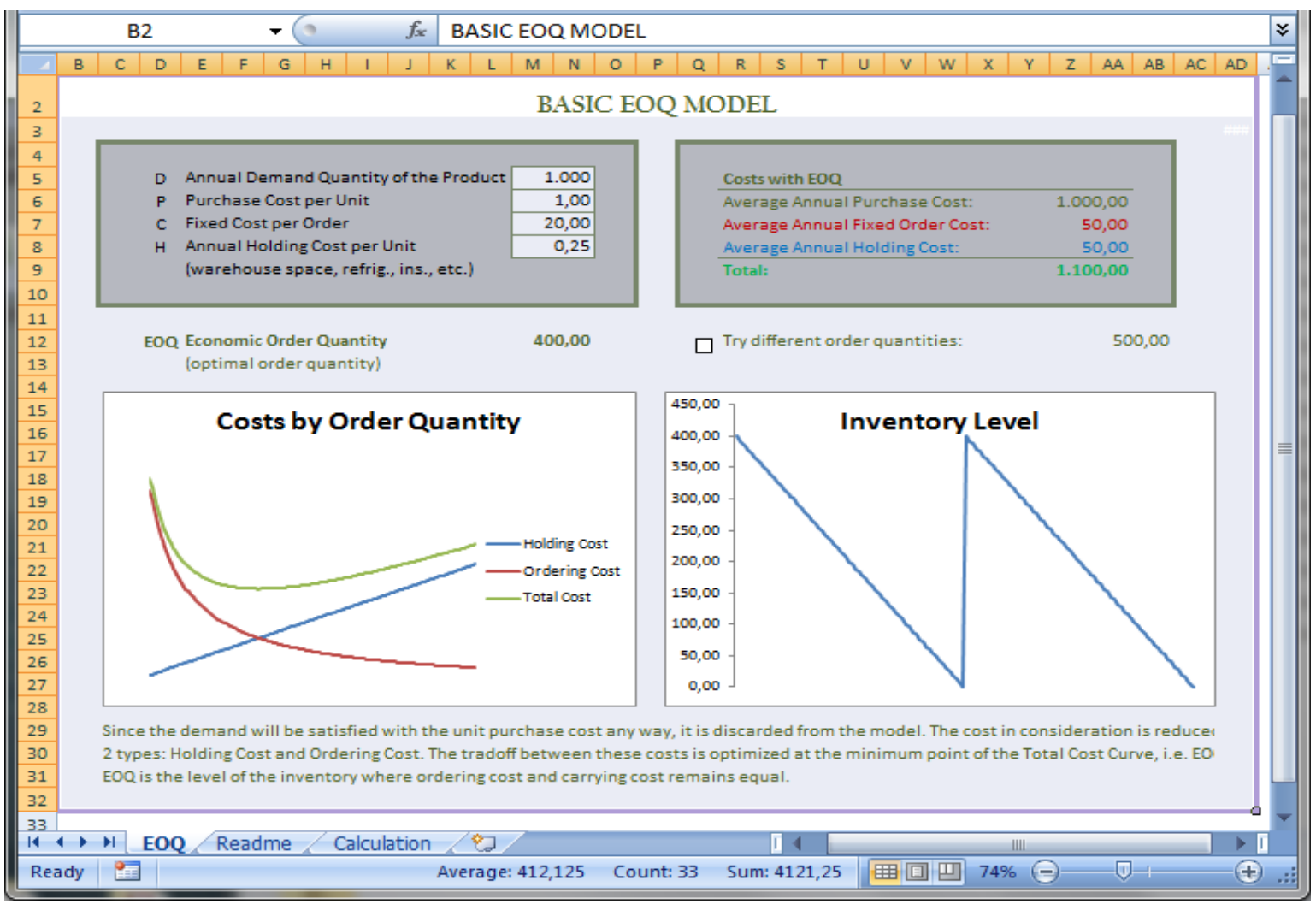

Slika 11. Prikaz Microsoft Office osnovni EOQ model 


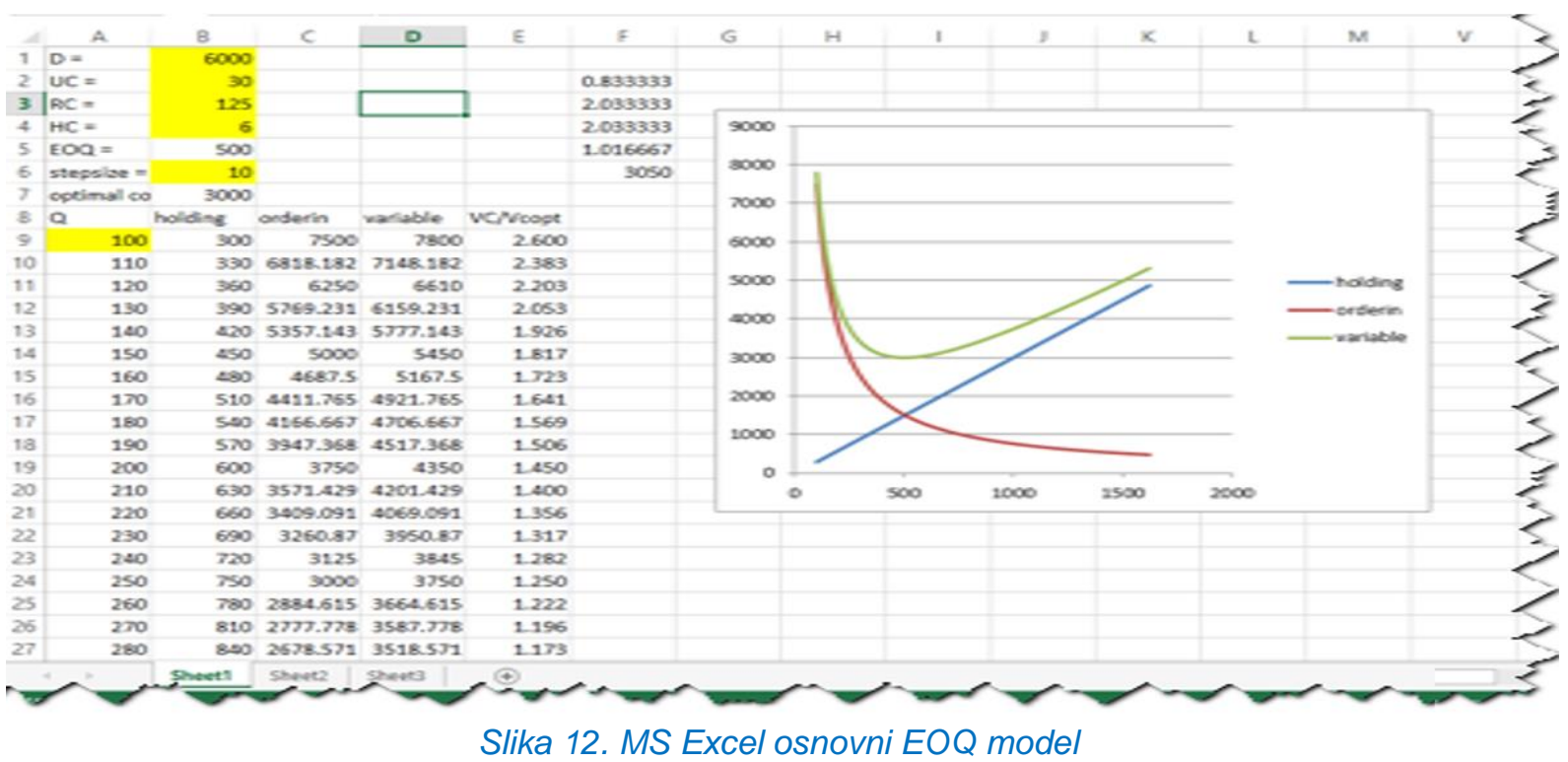

5 DISKUSIJA PREDNOSTI RAČUNARSTVA U OBLAKU

Primenom 6PL operatora su ostvareni uslovi za interakciju učesnika u lancu snabdevanja snabdevanje $u$ integrisanom informacionom okruženju. Ovi uslovi su izraženi u obliku ugovornih odnosa koji odražavaju stabilnu interakciju između učesnika. Kao osnovne prednosti cloud computing-a mogu se navesti:

- Servisi na zahtev-resursi se koriste samo onda kada su potrebni.

- Visoko apstrahovana infrastrukturaračunarske resurse korisnici koriste ne znajući gde se ti resursi nalaze niti kako su fizički organizovani.

- Elastičnost-resursi se fleksibilno obezbeđuju i oslobađaju, u zavisnosti od potreba.

- Merljivost-korišćenje resursa se može izmeriti i naplatiti po utrošku.

- Skalabilnost-infrastruktura može pratiti rast poslovnih potreba u realnom vremenu.

- Bolja iskorišćenost resursa-iste resurse može koristiti veći broj korisnika bez međusobnih uticaja.

Osnovni nedostaci cloud computing pristupa odnose se na još uvek neadekvatnu pravnu regulativu i nejasnoće $u$ nadležnostima. Na primer, preduzeća iz jedne države mogu koristiti usluge provajdera oblaka iz druge države, a podaci se mogu fizički čuvati u računarskom centru lociranom u trećoj državi (Regodić \& Stojanović, 2017). Takođe, postoji nedostatak jasnoće u pogledu licenci za softver, problemi u upravljanju digitalnim identitetima i pristupom, kao i problemi u garanciji dostupnosti servisa od strane provajdera (Matotek, Barać, Regodić, Grubor, 2015). Studija koju je sprovela kompanija Aberdeen Group pokazala je da organizacije koje koriste cloud usluge mogu da reše određene problem u prosečnom roku od 2.1 sata, dok je ostalim kompanijama potrebno u proseku oko 8 sati (SalesForce, 2014). Jedna od glavnih prednosti cloud computing-a je pristupačnost. Za razliku od tradicionalnih softvera, cloud softver je dostupna sa bilo kojeg računara, tableta ili smart telefona sa bilo koje lokacije. Za povezivanje cloud softvera sa korisnikom neophodna je samo Internet veza. Broj korisnika servisa se može menjati, a trošak se ne povećava rastom broja korisnika. Cloud computing usluge su obično po sistemu "pay as you go", tako da skoro i da nema potrebe za kapitalnim troškovima. Cloud computing povećava kolaboraciju između zaposlenih, gde god da se nalaze, i omogućava sinhronizaciju i rad na zajedničkim dokumentima i aplikacijama istovremeno. Istraživanje koje je sprovela kompanija Frost \& Sullivan pokazalo je da su kompanije koje su investirale u tehnologiju za kolaboraciju imale povrat od 400\% na investiciju (SalesForce, 2014). Preduzeća koja koriste cloud computing, zakupljuju samo resurse koji su im neophodni, i na taj način smanjuju troškove poslovanja, kao i negativan uticaj na životnu sredinu. Pored brojnih prednosti koje nosi upotreba cloud computing-a u poslovanju, neizbežno se javljaju i problemi i zazovi korišćenja ove tehnologije. Problemi korišćenja cloud computing-a u poslovanju se najčešće odnose na 
sigurnost čuvanja informacija o poslovanju. Cloud computing sa sobom nosi značajne rizike koji se odnose na privatnost i pouzdanost podataka koji se čuvaju u cloud-u.

Ulaganja u cloud computing usluge se konstantno povećavaju. International Data Corporation (IDC) predviđa da će ulaganja u cloud IT usluge iznositi 107 milijardi dolara u 2017, što je značajno povećanje u odnosu na 2013. kada su ulaganja iznosila 47.4 milijardi dolara (International Data Corporation, 2014). Cloud usluge menjaju način poslovanja i taj trend će se održati i u narednim godinama. Najzastupljeniji oblici e-trgovine su: Business-to-Consumer (B2C), Business-toBusiness (B2B), Consumer-to-Consumer (C2C), Social e-commerce, Mobile e-commerce (Mcommerce) i Local e-commerce. Na slici 13. (Laudon \& Traver, 2016) je dat prikaz rasta prihoda $B 2 C$ e-trgovine na globalnom nivou za period za period od 2000. do 2019. godine.

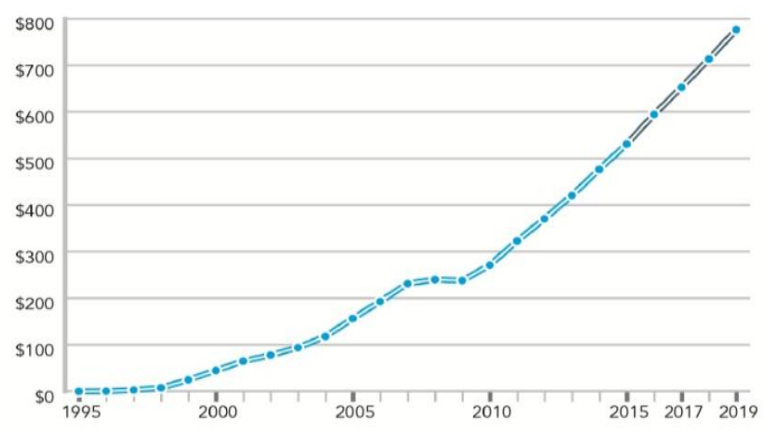

Slika 13: Prikaz prihoda B2C e-trgovine u milijardama USD za period od 2000. do 2019. godine.

Za period 2012-2017.godine B2B e-trgovina je porasla sa 4,1 na 6,6 trilionu dolara ili sa 40 na $42 \%$ od ukupne trgovine između kompanija, slika 14. Privatne industrijske mreže imaju primarnu ulogu u B2B e-trgovini (Laudon \& Traver, 2016).

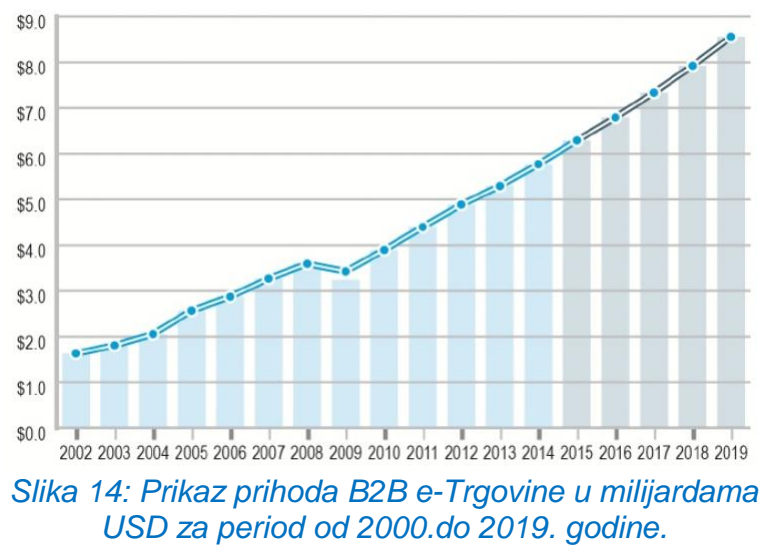

EDI trgovina ima i dalje značajnu ulogu. Na slici 15. je prikazano da je ne-EDI najbrže rastuća vrsta B2B e-trgovine, a EDI je zastupljena ali se vremenom smanjuje. Slika 15. (Laudon \& Traver, 2014) pokazuje da će elektronska tržišta postati dominantna oblik B2B e-trgovine.

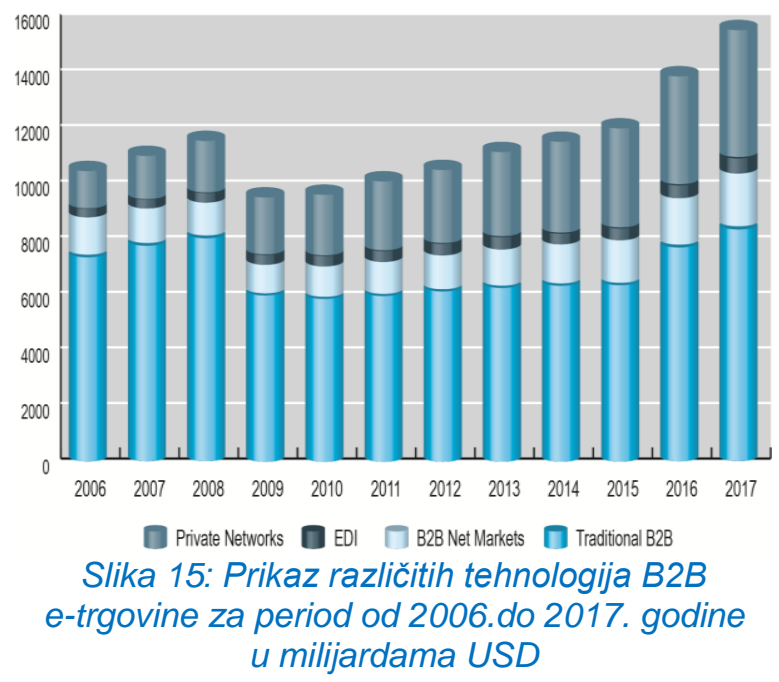

Posebna poboljšanja nastala kao posledica $\mathrm{B} 2 \mathrm{~B}$ trgovine su: unapređena je saradnja između kupca i prodavca, poboljšan kvalitet proizvoda, skraćeno je vreme proizvodnje, povećana je transparentnost cena, povećana vidljivost proizvoda i unapređena razmena informacija $u$ realnom vremenu. Sa rešenjima lanca snabdevanja u oblaku, SaaS ERP brzo raste i brojne organizacije prihvataju ovo rešenje.

\section{ZAKLJUČNA RAZMATRANJA}

Promene u okruženju savremenih kompanija, posebno nove, informacione tehnologije, uslovljavaju razvoj novog koncepta inovativne organizacije koja ima sledeće karakteristike: oslanjanje na tehnologije kao vitalnog resursa konkurentnosti; inovativna organizaciona kultura; jak (izražen) poslovni fokus; adaptibilnost; organizaciona kohezivnost; osećaj integriteta; angažovan top menadžment; pliće organizacione hijerarhije i viši stepen participativnosti (Regodić \& Cvetković, 2011).

Razvojem hardvera postojala je sve veća potreba za razvojem operacionih, analitičkih i specijalizovanih informacionih sistema. Cloud lanac snabdevanja informacioni sistem postaje faktor na osnovu kojeg jača konkurentska prednosti kompanije. Osnovna prednosti cloud-a u SC jeste povećanje efikasnosti i efektivnosti 
sistema. Cloud donosi značajan broj kvalitetnih rešenja: integralnost $u$ unošenju podataka, transparentnost $u$ poslovanju, poboljšanom finansijskom izveštavanju, smanjenje operativnih troškova, smanjenju administracije u obavljanju ovih operacija, kao i boljoj usklađenost procesa u celokupnom poslovanju. Softver Platforma 6PL se može koristiti u sistemima za upravljanje lancima snabdevanja zaliha, sistema planiranja proizvodnje, internet portala, kontrolnih sistema posrednička aktivnost. Softver 6PL platforma omogućava simulaciju procesa interakcije učesnika lanca snabdevanja, analizira statistiku interakcije i formira uslove interakcije, uzimajući u obzir autonomiju aktera. Primenom DSS Ekonomični model nabavke (EOQ, Economic Order Quantity) daje analitičko rešenje naručivanja neophodnih stavki i troškova držanja zaliha. Prednosti su u optimizaciji procesa u lancu snabdevanja. Autori su pokazali primenu modela upravljanja zalihama. Posebna pogodnost modela je u pojedostavljenju i racionalizaciji procesa nabavke.

Primenom 5PL logističkog operatera upravlja se mrežom različitih lanaca snabdevanja koji su povezani putem e-poslovanja. $U$ budućnosti možemo očekivati razvoj postojećih i stvaranje novih logističkih tehnologija (operteri od 7PL do $10 \mathrm{PL}$ ). Iz navedenog na evropskom tržištu preko logističkog operatera obavlja se $61 \%$ ukupnog transporta, 35\% skladištenja, $25 \%$ informacijskih sistema, $15 \%$ obrnute logistike, $13 \%$ menadžmenta materijalima, $11 \%$ prilagođavanje kupcima, $8 \%$ menadžment zalihama, $6 \%$ procesa narudžbi, $5 \%$ podrške klijenata te $18 \%$ ostalih logističkih aktivnosti, $s$ tendencijom daljnjeg povećanja učešća.

\section{CITIRANA DELA}

Armbrust, M., Fox, A., Griffith, R., Joseph, A. D., Katz, R., Konwinski, A., \& Zaharia, M. (2010). A view of cloud computing. Communications of the ACM, 53(4), 50-58.

Hillier, M. (1998, 09 28). Basic EOQ (Analitical). Preuzeto sa University of Nebraska-Lincoln: http://www.math.unl.edu/ tshores1/Public/Math428S08/Week16/Basic\%20EOQ\%20(Analytic al).xls

Hui, D., \& Yu, C. (2010). Cloud Computing, Accounting, Auditing, and Beyond. CPA Journal, 80(10).

Ivaschenko A. (2014). Multi-agentsko rešenje za upravljanje poslovnim procesima transportnog provajdera 5PL. Predavanja u obradi poslovnih informacija, Springer Intern. Publ., vol. 170, str. 110-120.

Ivashchenko, A.V., \& Peysakhovich, D.G., (2014). Metod proaktivnoy dispetcherizatsii V informatsionnoy srede dlya transportnykh operatorov 5PL. Informatsionnyye tekhnologii, (3), 49-54.

Laudon K.C., \& Traver C.G. (2014). E-commerce, business, technology, society, 6th Ed. AddisonWesley Pub (Sd).

Matotek, M., Barać, I., Regodić, D., \& Grubor, G. (2015). Supply Chain Risk Management Using Software Tool, Acta Polytechnica Hungarica, doi: 10.12700/APH.12.4.2015.4.10.

Mell, P., \& Grance, T. (2011). The NIST Definition of Cloud Computing: Recommendations of the National Institute of Standards and Technology. Preuzeto sa http://csrc.nist.gov/publications/ nistpubs/800-145/SP800

Mišković, V. (2013). Sistemi za podršku odlučivanju. Beograd: Univerzitet Singidunum.

Quinn, M., Strauss, E., \& Kristandl, G. (2014). The effects of cloud technology on management accounting and business decision-making. Financial Management. August. 54-55.

Regodić, D., \& Stojanović M., (2017). The Significance of the Integrated Multicriteria ABC-XYZ Method for the Inventory Management Process, Acta Polytechnica Hungarica, 14(5), 29-48. doi: 10.12700/APH.14.5.2017.5.3 
Regodić, D., \& Stojanović M. ( 2015). Uticaj informaciono-komunikacionih tehnologija na ekonomski rast. Zbornik radova Sinergija 2015, pp. 105-108. Bijeljina: Univerzitet Sinergija. doi:10.7251/ZRSNG1501105S

Regodić, D., \& Stojanović M., (2016). The Improvement of the Inventory Process in the Company "Benlian Food" Niš by Applying the Pom-Qm 4.0 Software. Sinteza 2016, doi: 10.15308/Sinteza-2016-257-264, pp. 257-264. Univerzitet Singidunum.

Regodić, D. (2014) Logistika-lanci snabdevanja, Beograd: Univerzitet Singidunum, ISBN 978-86-7912564-4.

Regodić, D., \& Cvetković, D. (2011). Automatizacija, proizvodni sistemi i računarski integrisana proizvodnja. Beograd: Univerzitet Singidunum, ISBN 978-86-7912-367-1.

Turban, E., Aronson, J.E., Liang, T., \& Sharda, R., (2010). Decision Support and Business Intelligence Systems, 9th Ed. Pearson Education, Inc.

Datum prve prijave:

16.03.2018.

Datum prijema korigovanog članka: $\quad 12.09 .2019$.

Datum prihvatanja članka: 27.03.2019.

Kako citirati ovaj rad? / How to cite this article?

Style - APA Sixth Edition:

Regodić, D., Matotek, M., \& Regodić, R. (2019, 04 15). Primena inteligentnih tehnologija pri upravljanju lancima snabdevanja. (Z. Čekerevac, Ur.) FBIM Transactions, 7(1), 134-151. doi:10.12709/fbim.07.07.01.16

Style - Chicago Sixteenth Edition:

Regodić, Dušan, Marija Matotek, i Radomir Regodić. 2019. „Primena inteligentnih tehnologija pri upravljanju lancima snabdevanja." Urednik Zoran Čekerevac. FBIM Transactions (MESTE) 7 (1): 134-151. doi:10.12709/fbim.07.07.01.16.

Style- GOST Name Sort:

Regodić Dušan, Matotek Marija i Regodić Radomir Primena inteligentnih tehnologija pri upravljanju lancima snabdevanja [Časopis] // FBIM Transactions / ur. Čekerevac Zoran. - Beograd : MESTE, 1504 2019. - 1 : T. 7. - str. 134-151.

Style - Harvard Anglia:

Regodić, D., Matotek, M. \& Regodić, R., 2019. Primena inteligentnih tehnologija pri upravljanju lancima snabdevanja. FBIM Transactions, 15 04, 7(1), pp. 134-151.

Style - ISO 690 Numerical Reference:

Primena inteligentnih tehnologija pri upravljanju lancima snabdevanja. Regodić, Dušan, Matotek, Marija i Regodić, Radomir. [ur.] Zoran Čekerevac. 1, Beograd: MESTE, 1504 2019, FBIM Transactions, T. 7, str. 134-151. 